\title{
SELF-RELIANCE THROUGH INNOVATION AND ENTREPRENEURSHIP COMPETENCY OF TECHNICAL/ENGINEERING POLYTECHNIC STUDENTS IN NIGERIA
}

\author{
Shirka Kassam Jwasshaka, Nor Fadila Mohd Amin, and Gimba Dogara \\ Department of Technical and Engineering Education, Faculty of Education, Universiti Teknologi Malaysia, Malaysia \\ E-mail: cassak4real@yahoo.ca
}

\begin{abstract}
The study aimed at assessing the adequacy of innovative and entrepreneurial competency of Technical /Engineering students of Plateau State Polytechnic for self-reliance. It was primarily sought to determine whether they were capable of setting up small-scale business after graduation. Three research questions were formulated to seek opinions of final year Technical and engineering students. A descriptive survey design was adopted where 120 respondents were randomly selected from the School of Technical Education and Engineering. 45 items structured questionnaire was used for the collection of data related to innovation and entrepreneurship competency in order to be self-reliant. The instrument was validated by three experts; two from Plateau State Polytechnic and one from the private sector. Data were analyzed using the descriptive statistic to determine the mean and the standard deviation of respondents. The findings of the study revealed that final year students need innovative and entrepreneurial competencies for self-reliant after graduation. The study also showed that the training provided is not sufficient for the prospective graduates to be able to face the challenges in the myths of job scarcity. Recommendations based on the findings of the study was highlighted which includes the need for a complete overhauling of Technology Education curriculum to reflect the current realities.
\end{abstract}

Keywords: competency, entrepreneurship, innovation, self-reliant

\section{INTRODUCTION}

The present face of the global economy has led to repeated calls for enhancement of selfreliance of citizens through a functional education. A school curriculum embedded with entrepreneurship programs is being advocated. This clarion call has ginger many countries in the world to re-evaluate their investment in education systems. Consequent upon the above, there has been a consistent call from Nigerian for increasing innovative and entrepreneurial curriculum content for a functional educational system [1]. Enriching the training curriculum with entrepreneurial skills may make students be self-reliant after graduation from schools. Entrepreneurial competency of students is important for sustaining a competitive global economy that is characterized by innovation.

Innovation is defined as a purposeful and positive change towards improving or replacing an existing idea or thing for the upkeep and worthwhile of any given society. Innovative entrepreneurial skills in the context of this study refer to the ingenuity of graduates to identify and utilize their talents to bridge the gap between the school and the labor market so as to be selfreliant in the society [2]. Innovation is a means of solving identified problems so it ought to be purposeful if it must be worthwhile. Innovative competency is all about diversifying knowledge and skills in manipulating the environmental opportunities waiting to be tapped to address any problem at hand. Musta'amal et al. [3] emphasize that creative and innovative thinking in the educational system can make graduates more transformed individuals for a successful future life.

Entrepreneurial competency, on the other hand, is the ability of the individual to use the innovative skills to establish a business for his benefit and the benefit of the society at large. 
Rebecca \& Benjamin cited in Onah et al. [4] asserted that entrepreneurship is all about learning the skills required to assume the risk of establishing a business and developing the winning strategies and executing them with vigor, persistence, and passion needed to succeed. The authors emphasized the need for entrepreneurs to be innovative if they want to achieve their desire of becoming self-reliant. An entrepreneur has to be creative and innovative in his skills to be able to adapt and respond swiftly to the societal needs. Acquiring entrepreneurial skills is very paramount for an entrepreneur to succeed. Entrepreneurship skills give the entrepreneur ability necessary for self-reliant in the society. Oliver \& Hyacinth [5] describe entrepreneurial skills competency as a set of achievements, understanding and personal attributes that make individuals more likely to be self-reliant and successful in his chosen career.

Technical / Engineering graduates are supposed to be craftsmen and women entrepreneurs who should be adequately trained, competent and innovative in establishing selfemployed organizations, micro-enterprises, and small-scale enterprises. Hilton [6] observed that instilling innovative and entrepreneurial skills in students is worthy because it is capable of influencing and facilitating their success in future workplace and citizenship.

Woodcock [7] advised that acquiring a degree is not enough but may be augmented with innovative skills, abilities, and personal entrepreneurial competency. Nigeria Economic Summit [8] observed that local institutions lack the capacity to nurture leaders who are thoroughly trained to take on global challenges. However, for us, as a nation to rise up to these challenges, our institutions of learning must work harder to adequately train Technical/Engineering students who are innovative and well equipped with entrepreneurial competencies for a lifelong employment in the face of this global challenges of unemployment. $\mathrm{Wu}$ et al. [9] affirmed that innovation is closely related to an individual's knowledge so is a powerful tool that may assist students to overwhelmingly overcome their professional challenges.

Unemployment is a cankerworm that has eaten deep into the fabric of the Nigerian society owing to the churning of a large number of graduates into the labor market with inadequate or no innovative and entrepreneurial competency needed for self-reliant. Records from the National Bureau of Statistic, Nigeria, (2018) shows that the unemployment rate increased to 18.80 percent in the third quarter of $2017,16.20$ percent in the second quarter of the same year. There may be a significant increase in 2018 report. In fact, unemployment increased day-by-day perhaps because the graduates are unskilled and always rely on scarce government jobs. In view of this ugly train, Nigeria higher education system is seen more in the negative light. Graduates who have skills fines it difficult to fit favorably into the labor market or be self-reliant because they do not have sufficient innovative and entrepreneurial competencies needed by the contemporary society.

If most of the graduates are unemployed, it means they do not have a creative ability or an entrepreneurial competency that is commensurate to their certificates as observed by Olaitan [10]. This may simply mean that the educational system in Nigeria today apparently do not equip its graduates to meet the challenges of the present time. Equipping graduates with creative ability and entrepreneurial competency especially in technical skills may go a long way in addressing the challenges of unemployment. This study, however, was aimed at assessing the adequacy of students' innovative and entrepreneurial skill competency in technical and engineering programs of Plateau State Polytechnic to determine whether they can be self-reliant with the kind of training being received. 
The main purpose of this study was to assess the innovative and entrepreneurial competency needs of technical/engineering students in Plateau State Polytechnic for selfreliant. The study specifically sought to assess (1) the innovative competencies needs of Technical/Engineering students for self-reliant, (2) entrepreneurial competency needs of Technical/ Engineering students in establishing a small scale business, and (3) adequacy of the training provided to the students to be able to cope with the innovative and entrepreneurial competency needs of the contemporary society.

\section{METHOD}

A survey research design was adopted for this study. This is found relevant to the study because the study sought to obtain the opinions of Technical/Engineering students about their innovative and entrepreneurial competency since they are about to enter into the labor market. Nworgu [11] explained that in a survey design, opinions of few can be surveyed and the results obtained generalized. The sample size for the study was 120 comprising 60 each of final year students from the schools of Engineering and Technical Education obtained by random sampling. The study was conducted in Plateau State Polytechnic Barkin Ladi. The choice of the institutions was informed by the fact that the institution mandate is to train technical men and women who are supposed to be self-reliant and add value to the economy.

The 45 items researchers formulated questionnaire was used for data collection in line with the formulated research objectives. The responses were on a five points Likert-type rating scale with response options as; Very highly needed (VHN), highly needed (HN), Needed (N), moderately needed (MN) and not needed (NN). The responses have a corresponding value of $5,4,3,2$, and 1 respectively. The instrument was validated by three experts, one from the industry and two from the Polytechnic. The data collected were analyzed using descriptive statistics with the aid of the Statistical Package for Social Sciences computer software (SPSS) to determine the Mean (X) and standard deviation (SD) of responses. The criterion for decision making was the real limit of the average mean of respondents $(1+2+3+4+5=15 / 5=3.00)$. This means that any mean scores of 3.00 and above are regarded as needed and any mean scores below is not needed.

\section{RESULTS AND DISCUSSION}

The results of the study are presented in Table 1 according to the first research questions about the innovative competency of Technical/Engineering students to be self-reliant. Table 1 presents the mean scores and the standard deviation of the respondents view on the innovative competencies needs of Technical/ Engineering students of Plateau State Polytechnic. From the results shown, all the items except for items 14 and 15 recorded mean scores below the decision rule of 3.00 . This is an indication that the students need these innovative skills for them to be self-reliant. The results recorded that the students lack skills in using a computer to perform tasks and opportunity to display hidden talents as indicated in items 14 and 15 , they have other relevant skills to be able to execute certain projects.

The second research question is about the entrepreneurial competency needs of Technical/ Engineering students in establishing a small scale business. They are presented in Table 2. Table 2 presents mean scores of the respondents' feelings about the entrepreneurial competencies needs of Technical /Engineering students in establishing a small scale business. The results show that the respondents rated all the items as being needed to be able to establish small-scale business except item 21 and 22 which has the mean scores below 
the decision rule. Similarly, the standard deviation which ranges from 0.987 to 1.30 indicates closeness in the opinions of the respondents. On the other hand, the third research question examines the adequacy of training provided to the students to be able to cope with the innovative and entrepreneurial competency needs. The respondent views on the Innovative competencies needs of Technical/Engineering Students to be self-reliant are shown in Table 3 . The results in Table 3 reveal the mean scores of the respondents' views on the adequacies of training provided to Technical/Engineering students for self-reliance. The results show that even though the students have no adequate knowledge in exposure to various exhibition programs which have the mean scores below 3.00 , the students, however, are adequately trained in the remaining 14 items which have mean scores above 3.00. The results also show the standard deviation range from 0.963 to 1.285 this indicates that the respondents were not too far from one another in their responses and indicated that the items were valid.

Table 1. The Respondent Views on the Innovative Competencies Needs of Technical/Engineering Students to be Self-Reliant

\begin{tabular}{llccc}
\multicolumn{1}{c}{ Items } & Mean & SD & Decision \\
\hline 1 & Ability to formulate programs objectives & 3.40 & 1.16 & Needed \\
2 & The ability of job analysis & 3.25 & .99 & Needed \\
3 & Determination of operational procedures & 3.35 & 1.12 & Needed \\
4 & Determination of program standards & 3.00 & .95 & Needed \\
5 & The arrangement of various tasks in their appropriate sequence & 3.25 & 1.06 & Needed \\
6 & Competency in the design of models & 3.42 & 1.07 & Needed \\
7 & Ability to diversify skills & 3.44 & 1.19 & Needed \\
8 & Application of skills other than those acquired in your own area of study in & & & \\
& accomplishing tasks & 3.19 & 1.12 & Needed \\
9 & An orderly arrangement of tools and equipment & 3.36 & 1.03 & Needed \\
10 & Ability to interpret various working drawings & 3.63 & 1.12 & Needed \\
11 & Knowledge of care of tools and equipment & 3.64 & 1.05 & Needed \\
12 & Foreknowledge of synergy with the industries in skills training & 3.24 & 1.14 & Needed \\
13 & Familiarity with various relevant materials, tools, equipment, and machinery used & 3.22 & 1.20 & Needed \\
& to perform a tasks & 2.82 & 1.31 & N/needed \\
14 & Competency in using computers to perform tasks & 2.81 & 1.24 & N/needed \\
15 & The opportunity provided to display hidden talents & & \\
\hline
\end{tabular}

Table 2. The Entrepreneurial Competencies Needs of Technical/Engineering Students in Establishing Small Scale Business

\begin{tabular}{clccc}
\hline S/N & \multicolumn{1}{c}{ Items } & Mean & SD & Decision \\
\hline 16 & Competencies in displaying proficiency & 3.14 & 1.14 & Needed \\
17 & Ability to handle emotional or psychological problems of individuals & 3.01 & 1.12 & Needed \\
18 & Competency in spotting problems early enough & 3.11 & 1.06 & Needed \\
19 & Identifying and applying correct steps to problem-solving & 3.28 & 1.05 & Needed \\
20 & Consistency in decision making & 3.11 & .99 & Needed \\
21 & Knowledge of quality control of finished products & 2.99 & 1.04 & N/needed \\
22 & Managerial competency & 2.99 & 1.06 & N/needed \\
23 & Identification of sources of funds & 3.18 & 1.14 & Needed \\
24 & Knowledge of statutory registration of a business organization & 3.14 & 1.14 & Needed \\
25 & Competency in the choice of suitable business location & 3.22 & 1.06 & Needed \\
26 & Ability to evaluate business progress & 3.21 & 1.03 & Needed \\
27 & Competency in time management & 3.19 & 1.24 & Needed \\
28 & Attendance of workshops, seminars, and Conferences organized by other & 3.01 & 1.30 & Needed \\
& professionals & & & \\
29 & The ability to record keeping & 3.36 & 1.08 & Needed \\
30 & Knowledge of marketing strategy & 3.57 & 1.15 & Needed \\
\hline
\end{tabular}


Table 3. The Views of the Respondents on the Adequacies of Training Provided to Technical /Engineering Students to be SelfReliant

\begin{tabular}{|c|c|c|c|c|}
\hline $\mathrm{S} / \mathrm{N}$ & Items & Mean & SD & Decision \\
\hline 31 & Identification of the functions of various tools and equipment & 3.54 & 1.17 & Adequate \\
\hline 32 & Allocation of sufficient time for practical & 3.06 & 1.19 & Adequate \\
\hline 33 & Demonstration of tasks by the instructors & 3.08 & 1.15 & Adequate \\
\hline 34 & Competency in maintenance work & 3.17 & 1.15 & Adequate \\
\hline 35 & Execution of tasks under the strict supervision of the instructor & 3.38 & 1.12 & Adequate \\
\hline 36 & Mastery of skills in own areas of specialization & 3.21 & 1.00 & Adequate \\
\hline 37 & Exposure to relevant industrial work & 3.18 & 1.09 & Adequate \\
\hline 38 & Practicing the tasks demonstrated by the instructor & 3.15 & 1.13 & Adequate \\
\hline 39 & Carrying out a particular task as a project & 3.29 & 0.99 & Adequate \\
\hline 40 & Competency in using modern tools and equipment to perform tasks & 3.15 & 1.29 & Adequate \\
\hline 41 & Knowledge of information and communication technology & 3.31 & 1.15 & Adequate \\
\hline 42 & Competency in observing workshop ethics & 3.24 & 0.97 & Adequate \\
\hline 43 & Prior knowledge of professional prospects & 3.21 & 0.96 & Adequate \\
\hline 44 & Competency in identifying materials and their properties & 3.17 & 1.21 & Adequate \\
\hline 45 & Exposure to various exhibition programs & 2.67 & 1.10 & N/ Adequate \\
\hline
\end{tabular}

The findings from the study in research question 1 as presented in Table 1 revealed that 13 of the 15 items have mean scores of the respondent views range from 3.00 to 3.64 except for items 14 and 15 which have above the decision rule of 3.00. This clearly showed that the students need innovative competencies outlined, in order to be self-reliant after their training. These competencies include ability to formulate programs objective, ability of job analysis, determination of operational procedures determination of program standard, arrangement of various tasks in their appropriate sequence, competency in design of models, application of skills other than those acquired in own area of study in accomplishing a task, orderly arrangement of tools and equipment, having foreknowledge of synergy with the industries in skill training, familiarity with various relevant materials, tools, equipment and machines used to perform a tasks, except competency in using computers to perform tasks and opportunity provided to display hidden talents. The finding is supported by the study carried out by Maigida [12], who observed that changes in the labor market have called for innovations and expansion of skills to meet up the challenges.
Table 2 displays the mean scores of the data from the respondents' views about the entrepreneurial competencies needed by Technical/Engineering students in establishing a small scale business. The mean score ranges from 3.01 to 3.57 of 13 out of 15 items which are above the acceptable standard of 3.00. Therefore, the findings show that the students required 13 of the entrepreneurial competencies to enable them to establish a small-scale business. Woodcock [7] in his study cautioned that acquiring a degree is not enough but should be augmented with creative skills, abilities and personal entrepreneurial competencies in order to succeed. The finding of this study agreed with the study of Okpetu in Obunadike [13] where it asserted that entrepreneurship equips students with skills that help them to be self-employed when they graduate. This could, however, be concluded that apart from having a certificate in which the students are trained, they should also be well equipped with diverse skills to be able to set up business on their own to avoid over-dependence on the scarce government jobs.

The third research question was sought to find out about the adequacy of training received by Technical/Engineering students for self-reliant 
and the result in Table 3 revealed the mean scores of the respondents' views concerning this. The mean score of 14 out of 15 items ranges from 3.06 to 3.54 far above the decision rule of 3.00. This means that there is adequate training provided to the students to be self-reliant after graduation, but unemployment still persists perhaps because of their inability to identify their capabilities. The findings are in line with the study of Okorie in Kassam \& Gbiang [14] which asserts that adequacy of the skill gained by an individual depends upon the ability to use his training in gainful employment. The source also added that individual must be trained so that he can secure and hold employment and so succeed productively, he must be trained to meet the market demands of his occupation. Okorieocha \& Taneh [15] revealed in their study that Technical and Technology education is expected to produce a new breed of a competent workforce who can excel in the rapidly changing environment and then improve the country's economy. This can only be achieved by training individuals who are expected to go and influence the society positively with adequate entrepreneurial skills needed.

\section{CONCLUSION}

In view of the high competition in the world of work with a consequent high number of graduate into the labor market yearly, there is an urgent need for entrepreneurial skills to enable them to establish small-scale business thereby reducing this ugly train. Literature has revealed that a certificate is not just enough but it should be augmented with marketable skills. The vision of technology education is not a mere theoretical framework, it is based on functional knowledge and experience that can lead to gainful employment amongst graduates. Students, on the other hand, should be committed to studying professional courses that are aimed at making them self-reliant. Based on the findings of the study, there is a need for a complete overhauling of the school curriculum content to reflect the present reality of life i.e. it should be made in such a way that more emphasis is placed on entrepreneurial skills instead of being occupied with the theoretical content curriculum. In providing these entrepreneurial skills to students, various institutions of learning should have a synergy with the industries in order to provide real-life training situation to the students. Institutions of learning should emphasize competitive exhibition of students practical to encourage other students to display their hidden talents. Training tools in the institution should be the replica of what students should expect to meet in workplaces after leaving school.

\section{REFERENCES}

[1] C. C. Nsofor, A. E. Umeh, B. Ahmed, and A. W. Idris, "Creating Self-Reliant Opportunities through Entrepreneurial and functional Educational Technology: Panacea for Nigeria's Youth Unemployment," J. Educ. Pract., vol. 5, no. 35 , pp. 30-35, 2014.

[2] C. M. Chinwe and C. O. Eboka, "Acquisition of Innovative and Entrepreneurial Skills in Basic Science Education for Job Creation in Nigeria," Sci. Educ. Int., vol. 28, no. 3, pp. 207-213, 25AD.

[3] A. H. Musta'amal, N. Mohtaram, N. Rosmin, and M. A. Fakhruddin, "Creativity amongst Final Year Students of Polytechnic Diploma," J. ILMI, vol. 7, no. 1, pp. 75-86, 2017.

[4] O. Onah, C. Osinem, E., and M. Onu, F., "Entrepreneurship Skills Required by Secondary School Graduates in Yellow Pepper Production Enterprises in Nsukka Agricultural Zone of Enugu State Nigeria," Int. J. Educ. Res. Univ. Niger., vol. 12, no. 2, p. 161, 2013.

[5] B. Oliver, Y. and O. Hyacinth, I., "Employability Skills Required by 
Business Education Graduates for the Global Workplace as Perceived by Employers in Enugu Metropolis," Int. J. Educ. Res. Univ. Niger., vol. 12, no. 2, p. 149, 2013.

[6] M. Hilton, "Preparing Students for Life and Work," Issues Sci. Technol., vol. 31, no. 4, p. 149, 2015.

[7] B. E. Woodcock, What are Employability Skills? Canterbury: Careers and Employability Serice, University of Kent, 2012.

[8] Nigeria Economic Summit Group, "19th Nigerian Economic Summit," Lagos, 2013.

[9] M. Wu, I. Siswanto, W. Suyanto, Y. G. Sampurno, and W. Tan, "Creative Thinking Curriculum Infusion for Students of Teachers' Education Program," J. Pendidik. Teknol. dan Kejuru., vol. 24, no. 1, pp. 1-12, 2018.

[10] S. O. Olaitan, Curriculum Development and Management in Vocational Technical Education. Onitsha: Cape publishers Int. Ltd, 1999.
[11] B. G. Nworgu, Educational Research, Basic Issues, and Methodology. Ibadan: Wisdom Publisher Ltd, 2006.

[12] F. Maigida, J., "Assessment of the Role of TVET in the Reduction of Unemployment among Youths in Nigeria," J. Technol. Educ. Res., vol. 5, no. 1, pp. 6-12, 2012.

[13] J. C. Obunadike, "Relevance of Teachers Attitude and Willingness in Implementing Integration of Entrepreneurship Education into Secondary School Curriculum for Quality Assurance," Int. J. Educ. Res. Univ. Niger., vol. 12, no. 2, p. 123.

[14] S. J. Kassam and B. Gbiang, P., "Work Skill Require by Building Technology Education Students in Contemporary Nigeria; the Way Forward," in the 15th International Conference of the Nigeria Vocational Association, 2010.

[15] C. N. Okorieocha and N. Taneh, "the Roles of Technical and Vocational Education and Training in Industrialization and Economic Development in Nigeria." 